\title{
Government Response to Handling Covid-19 Study Comparation: Lessons Learned from Taiwan and Indonesia
}

\author{
Sitti Aminah* \\ Research and Development Board \\ Ministry of Home Affairs \\ Indonesia \\ sittiaminah.kemendagri@gmail.com \\ J Josep \\ Research and Development Board \\ Ministry of Home Affairs \\ Indonesia
}

\begin{abstract}
The Covid-19 pandemic has caused infections cases and deaths of people, damaged healthcare systems, and declining economies. All countries have responded the pandemic through various policies. The study aims to compare the response of the Taiwan and the Indonesian in dealing with the Covid-19 pandemic. Qualitative methods are used by adopting a multi-case approach in Taiwan and Indonesia. The data collection technique relies on literature studies sourced from scientific journals, online media, and government policy documents. The data were analyzed using a qualitative descriptive technique involving data reduction and data displaying. The study found that the Taiwan Government was successful because of the government's rapid responses to deal with the Covid-19, even before the first case was detected. The government implemented some efforts to contain the virus: closing entrances in border areas, detecting infected people through massive tests, tracking out infection cases using digital technology, enforcing sanctions to prevent disinformation, reinforcing the compliance of the citizen to the quarantine policies, and maintaining effective communications with its citizen. Meanwhile, the Covid-19 handling in Indonesia was relatively slow. At the beginning, the public officials' denials of the virus existence has caused some problems, such as disharmony between the central and local government and weak coordination, the inconsistency of border entrances policies, limited medical personnel and personal protective equipment, the expensive PCR testing, limited infected tracking, the weak sanctions, and the effectiveness of the government communication.
\end{abstract}

Keywords--Government Response; Handling Covid-19; Comparative Study

\section{INTRODUCTION}

Since the end of 2019, the world has faced a massive Covid-19 pandemic. The new type of coronavirus was discovered in Wuhan, a city of 10 million people. People were found to be infected by the coronavirus and suffered an acute respiratory illness, causing many deaths. On January 23, 2020, at $2.00 \mathrm{am}$, the Wuhan government announced the city lock down from 10:00 am. Residents who were anxious of the lockdown fleet Wuhan, then the virus began to spread worldwide [1]. The Covid-19 pandemic caused a collapse of health care systems and economic recession in many countries.

The governments of all countries are responding to the Covid-19 pandemic through policies, such as closing borders, quarantine, and physical distancing. In order to contain the

\author{
G Gunawan \\ Research and Development Board \\ Ministry of Home Affairs \\ Indonesia
}

R Rosidah

Research and Development Board

Ministry of Home Affairs

Indonesia

spread of the virus, there are two fundamental strategies for dealing with a global pandemic, namely: (a) mitigation, focusing on slowing and stopping the spread of the pandemic - thus reducing the peak demand for health care while protecting those most at risk, (b) suppression, which aims to reverse the growth of the epidemic, reducing the number of cases to low levels, and maintain the situation [2]

Taiwan has been very successful in dealing with the Covid 19 pandemic. Although a preliminary study conducted by John Hopkins University in January predicted that Taiwan would have the second-highest cases after China [3], Taiwan was able to withstand the infection and death rates due to the Covid-19 pandemic and recorded the lowest death toll in the world without a lockdown scheme. Ten months after the spread of the Covid-19 pandemic, based on data source from Worldmeter on October 2020, the confirmed cases of Covid-19 were 554 with only 7 deaths. This made up the total deaths per 1 million population was 03 . In contrast, the covid-19 handling in Indonesia was rather slower than Taiwan. Based on Worldmeter data, Indonesia is the country with the highest infection cases in Southeast Asia and ranks 16th out of 191 countries in the world. There were 410,088 infection cases and 13,869 deaths [4].

TABLE I. Comparison of Infection Cases and Deaths in Taiwan and Indonesia

\begin{tabular}{|c|l|c|c|c|c|}
\hline \multirow{2}{*}{ No } & Country & $\begin{array}{c}\text { Total } \\
\text { Case }\end{array}$ & Deathl & $\begin{array}{c}\text { Total } \\
\text { Case/1million } \\
\text { Population }\end{array}$ & $\begin{array}{c}\text { Total Death/1 } \\
\text { Million } \\
\text { Population }\end{array}$ \\
\hline 1 & Taiwan & 554 & 7 & 23 & 0,3 \\
\hline 2 & Indonesia & 406.945 & 13.782 & 1483 & 50 \\
\hline
\end{tabular}

Sources: Worldometer, 30 October 2020.

Studying the success or failure of some countries in dealing with the Covid-19 pandemic as an opportunity for citizens to learn what the government has done during the pandemic crisis through various policies [5]. The present study aims to compare the policies of the Taiwanese government and the Indonesian government in dealing with Covid-19. This comparison is important to see successful government policies in other countries as a lesson learnt for improving policies on Covid-19 handling in Indonesia.

The study uses the public policy concept to analyze why Taiwan succeeded and why Indonesia was less 
successful in handling the Covid-19 pandemic. Literature records variety of definitions of public policy. In this study, the definition of public policy accords with Dye who defines public policy as the government choices to do or not to do certain things [6]. In this context, the government remains silent about an issue, which is a public policy. In this study, the policy is interpreted as a decision containing principles to direct the government's response in a planned and consistent manner to deal with the Covid-19 pandemic. Analyzing the response of the Government of Taiwan and Indonesia, this study refers to the guidelines set by WHO as a guide for national governments to overcome the pandemic crisis which includes [7]:

1. Planning and coordination (the level of preparedness of a country can be seen based on whether there is good cross-sectoral leadership and coordination in responding to a pandemic. State policies can be integrated into the national emergency preparedness framework.

2. Monitoring and conclusion of the situation (closely related to not only data and information about the situation itself, but how the data and information can be used to respond more effectively.

3. Prevention of the spread of disease (policies affecting individuals / households, communities, reporting activities across national borders)

4. Sustainability of health services (related to health readiness and services, including groups of medical personnel)

5. Public community (the government's ability to provide adequate information with the principles of openness, fairness, and accuracy so that the public is informed and makes the right decisions.

\section{MethodS}

The study employs a qualitative method by adopting a multi-case approach [8]. This approach is considered appropriate to confirm the Covid-19 handling schemes of the two different countries, Taiwan and Indonesia. The comparison between the two governments refers to a research design popular among comparative socio-political scientists. The choice of Taiwan as the object of study was due to the reason that this country has a low infection and death rate due to Covid-19 in the world. Besides, Taiwan and Indonesia have similarities in implementing democracy in government, namely considering and implementing freedom and civil rights, supporting openness and validity of the information. The data collected in this study were related literature about Covid-19 handling in Taiwan and Indonesia from scientific journals, online media, and printed media. In addition, data from reports, statistics and government policy documents regarding the handling of the Covid-19 pandemic were also used. Processing and analysis of data used a qualitative descriptive technique. The first phase was collecting data on policies for handling the Covid-19 pandemic in Taiwan and Indonesia, on the following aspects: (a) planning and coordination, (b) prevention policies, (c) sustainability of health services, and (d) government public communications. The second phase was reducing the data which were not relevant to these four aspects. The third and the fourth phases were displaying the findings and setting up lessons learned of the successful government.

\section{RESULT AND DISCUSSION}

\section{- Taiwan Government Response: Speed of Action}

Planning and Coordination. Taiwan's pandemic response was largely mapped out through extensive planning as a result of the SARS pandemic in 2003 and was developed in such a way that it could be adapted to new pathogens [9]. The government response was immediate when the virus was still difficult to be understood, also the level of transmission was still not clear. There were some triggering factors which increased the government awareness of the pandemic. Taiwan is located close to China Mainland, only separated by sea border. Taiwan and China are separated only by the Formosa Strait, a distance of 130 KM. Also, every day 400,000 Taiwanese live in Taiwan and across the Formosa Strait. Taiwan, with an area of 35,801 $\mathrm{km} 2$, has a population of around 24 million people with a high density. This reason triggered the government to organize a coordinated national response at the early wave of the pandemic [10].

The Taiwanese government announced a confirmed case of Covid-19 on January 2, 2020, namely a 50-year-old woman who returned to Taiwan after working as a teacher in Wuhan [11]. The government responded long before the cases have emerged. Since December 31, temperature and health checks for airplane passengers from Wuhan were placed. Guidelines containing how to deal with a pandemic, the Influenza Pandemic Strategic Plan has been established since 2012. The guidelines set five bases of defense, namely (1) restrictions on travel abroad, border control, control of epidemic management in the community, maintenance of health functions and systems, and protection of individuals and families.

To coordinate the roles of various government agencies in one command, the Taiwanese government made it effectively by the Central Epidemic Command Center (CECC) for Severe Special Infectious Pneumonia, which was activated on January 20, 2020. This institution was formed previously when the SARS pandemic hit Asian countries [13].

Pandemic Prevention Policy. After China notified WHO about the Pneumonia case in Wuhan City, the Taiwanese Government acted quickly, including (1) Issued a warning through the CECC to monitor the arrival of passengers from Wuhan. (2) Screening 26 suspected cases of the virus by sending a Team of Experts to China; (3) Activating CECC (4) Stopping all Flights from Wuhan on January 26, 2020. (5) Combining surveillance technology at airports using health big data and tracking technology to monitor citizens detected with virus infection, (5) Simultaneously in January, The government distributed 6.5 million masks, 84,000 liters of water, hand sanitizer, and 25,000 forehead thermometers [14].

The government limited activities across countries through (1) restricting international travel, as of March 21, 2020, Taiwan residents were strongly advised not to travel to all foreign destinations, (2) the government also prohibited cruise ships from making port calls since 
February 6, 2020, (3) all flights were prohibited from transiting in Taiwan since April 24, 2020 (Taiwan CDC, 2020 c). Individuals entering Taiwan were required to quarantine their respective residences for 14 days (CDC Taiwan, 2020d). Sanctions for violations of the quarantine rules will be subject to a fine of up to NT $\$ 1,000,000$ or Rp. $540,000,000$ [15].

Sustainability of Health Services. The Taiwan government ensures that personal protective equipment (PPE) for every medical worker is sufficient. Taiwan can produce 8.2 million marks per day. Around 5.2 million face masks were distributed to the general public, while another 3 million were allocated for hospital needs. The Central Epidemic Command Center (CECC) has supplied N95 masks and hazmat suits which are expected to meet domestic medical needs for the next 25 days [16]. Taiwan's well-developed pandemic approach, with extensive contact tracing through both manual and digital approaches, and access to travel histories, meant that potential cases could be identified and isolated relatively quickly [17]. The government is targeting testing of 38,000 per day throughout the island of Taiwan by providing 34 laboratories, including retests for people who were not previously known to have pneumonia.

The government allocated the budget of NT \$ 9.6 million or around 10.6 trillion Rupiahs in the sector of providing Covid-19 health services, compensation for medical personnel, and medical research [18]. Budget support allocated for the economic sector in the amount of NT \$. 1.6 million or 8.7 trillion rupiahs. Loans were given to small economic entrepreneurs by the Government. Including the budget stimulus for industrial sectors affected by Covid-19. The Government implemented a welfare program that provides a daily allowance of 30 US dollars (approximately Rp 450,000) for residents who stay in quarantine for two weeks [19].

Effectiveness of Public Communications. The Taiwan government provided various channels for the dissemination of Covid-19 information. During the pandemic, the Minister of Health held daily press conferences covered by all national media (Shapiro, 2020) [20]. Also, social media such as Facebook, Line, Youtube were used to disseminate Covid-19 information and policies. Education was carried out to the public to fight public disinformation. The Government established the Taiwan Fact Check Center, a non-profit organization to dispel fake news of Covid-19 [20]. Sanction to those who spread covid-19 disinformation and residents who violate quarantine rules. During the quarantine period, Taiwan used digital technology to monitor citizens by cellular signals and cell phones, known as digital "FENCE". The notification system will be automatically activated if someone goes far from his house, then the officer will call to inquire about their position. If residents leave their homes without carrying cell phones, the Government will use the M-Police tracking system to detect them. M-Police is a cloud computing system that contains various databases, including the identity and characteristics of individuals who are required quarantined [21].

\section{- Indonesian Government Response}

Planning and Coordination. The government has been slow to respond the Covid-19 outbreak. The government detected the first cases on March 2, 2020, around two months after the virus spread in Wuhan. At the beginning, the statement of government officials seems to ignore the threat of Covid-19. Unresponsive policies of government to Covid-19 handling, for example in January and February 2020, when the virus spread massively in China, South Korea, Italy and others; some countries have adopted policies to close transnational human permits. Instead, the Indonesian government adopted another policy that seeks to attract tourists and businesses from countries that are closing their countries to visit Indonesia [22].

There are no national guidelines for managing the pandemic situation. The absence of an early anticipation and response system caused the governance crisis. Several aspects that show the weakness of policies such as vertical and horizontal coordination, policy fragmentation, confusion of information, and indications of public doubt over the capacity of the state to manage crises [23].

Ineffective coordination created disharmony between the central and regional governments. Some of local governments - without coordination with the central government - have implemented lockdowns, including closing ports and airports as well as border areas. It happened because of the central government is considered slow to handling the Covid-19 pandemic [24]. Miscommunication arises when local governments decided to implement Large-Scale Social Restrictions (PSPB) in a sustainable manner, but the central government refused it with declined economy reason [25]. The implementation of mass transportation regulation is not in line with the PSPB policy. It has caused disharmony relation between the Ministry of Transportation and the local governments in Jakarta, the capital city of Indonesia. The Rapid Test-PCR import policy arised a polemic. Health experts refused import of Rapid Test-PCR because the rapid test was only used to diagnose antibodies that are formed when a person shows symptoms, Indonesia is also considered capable of producing RT-PCR [26].

However, the Government claimed that they have taken preventive steps for pandemic prevention. On January 27, 2020, the Ministry of Health announced that it had installed 195 thermal scanners at 135 national entrances and prepared 100 hospitals to treat patients identified or infected with Covid-19. On January 31, 2020, the Ministry of Health has also instructed hospitals to prepare isolation rooms. Then, on February 2, 2020, the government evacuated 238 Indonesian citizens from Wuhan, China, and quarantined them in the Natuna Islands for 14 days. Then On February 2, 2020, the Ministry of Foreign Affairs announced that it had decided to close access to and from China starting February 5, 2020. The Ministry of Law and Human Rights also terminated visa exemptions for China. On February 7, 2020, the Ministry of Manpower announced it would stop placing workers in mainland China [27].

Pandemic Prevention policy. The Large-Scale Social Restrictions (PSPB) policy is not optimal because of the requirements and criteria that must be met by the local government [28]. To implement PSPB, the Local 
Government must submit a proposal to the Ministry of Health by fulfilling several requirements, such as preparing data on case increases, local transmission incidents, basic living needs, the readiness of health infrastructure, budget, and operationalization of social safety and security net. After being submitted, the Minister of Health formed a special team to provide an epidemiology study. The team set up recommendations to the minister to accept or reject local government proposals implementation of PSPB policy.

The weakness of PSPB implementation in local areas is not all local governments formulated regulations to impose sanctions on residents who violate PSPB. Besides, there are no sanctions for local governments which refused to implement the PSBB, even though this area is the epicenter of the spread of Covid-19 [29].

The limitation of activities across national borders considered inconsistent. When the Government enacted the policy to ban foreign workers on February 2, 2020, the Indonesian Ministry of Foreign Affairs announced that it had closed access to and from China starting February 5, 2020. On February 5, 2020, the Ministry of Law and Human Rights temporarily suspended visa exemptions for China. On 7 February 2020, the Ministry of Manpower announced that it had asked Indonesian migrant worker placement companies to stop placing workers in mainland China. However, in early May the Central Government approved the gradual entry of 500 Chinese workers into the nickel mining area in Southeast Sulawesi, which led to resistance from various elements of the local government and society [30].

Health Service Problems. The handling of Covid-19 was challenged by the limited health workers. The distribution of medical personnel is uneven when compared to the population. Out of the 34 provinces, only 16 provinces in Indonesia are in accordance with WHO recommendations (180 / 100,000 population). Recently, there are 363 medical and health personnel who died from the corona virus. This number consists of 202 doctors, 15 dentists and 146 nurses. Meanwhile, the doctors who died consisted of 107 general practitioners (4 professors), 92 specialist doctors (7 professors), 2 residents, and 1 person in verification [31]. Hospital facilities are available, but logistics such as face masks and personal protective equipment for medical personnel are limited. Indonesia has tested 16,897 per total population, while Singapore has reached 661,251 per total population. Malaysia and the Philippines have reached 67,619 and 44,535 per total population [32].

TABLE II. Comparison of PCR Testing in Indonesia among ASEAN Countries

\begin{tabular}{|c|l|c|c|c|}
\hline No & Country & Population & $\begin{array}{c}\text { PCR } \\
\text { Testing }\end{array}$ & $\begin{array}{c}\text { PCR Testing/total } \\
\text { population }\end{array}$ \\
\hline 1 & Indonesia & 274.519 .163 & 4.638 .515 & 16.897 \\
\hline 2 & Singapore & 5.866 .231 & 3.879 .052 & 661.251 \\
\hline 3 & Thailand & 69.860 .842 & 977.854 & 13.997 \\
\hline 4 & Malaysia & 32.508 .341 & 2.198 .172 & 67.619 \\
\hline 5 & Viet Nam & 97.640 .614 & 1.246 .480 & 12.716 \\
\hline 6 & Myanmar & $54.535 . .935$ & 737.090 & 13.516 \\
\hline
\end{tabular}

Sources: Worldmeter, WHO, November, 32020

The high cost of the Covid-19 test hinders the tracing of infection cases, as presented in Table II [30]. Table III shows the gap in the price of the PCR test (SWAB) in Indonesia compared to ASEAN countries, namely around 1.5-5 million, Malaysia, 536 thousand rupiahs, Thailand, 13 million rupiah and the Philippines around 1-4 million rupiah, even Singapore is free. The high cost of PCR tests is because $90 \%$ of the Covid test machines and reagents rely on imports.

TABLE III. Comparison of Covid-19 Test Prices in Indonesia

\begin{tabular}{|c|c|c|}
\hline No & $\begin{array}{c}\text { ASEAN } \\
\text { Countries }\end{array}$ & Price of PCR Test \\
\hline 1 & Indonesia & Rp. 1.5-5 Million \\
\hline 2 & Malaysia & RM 150-250 (around 536.894 rupiahs) \\
\hline 3 & Philipina & P 4000-13000 (1,2-4 million rupiahs) \\
\hline 4 & Thailand & THB 2.500-6500 (1,1-3,08 million rupiahs) \\
\hline 5 & Singapura & $\begin{array}{c}\text { Free } \\
\end{array}$ \\
\hline 6 & Brunei & B \$ 100-200 (Rp. 1.09-2.18 million rupiahs) \\
\hline 7 & Cambodia & US\$ 100 (1,49 million rupiah) \\
\hline
\end{tabular}

Source:Tempo News, September, 152020.

To handling Covid-19, The government has allocated a budget for handling this Covid-19. Data released by the Ministry of Finance, amounting to Rp. 801.86 trillion. This covid-19 epidemic response fund is also included in it to overcome the impacts caused by Covid-19, namely in the health, social, economic and health sectors.

Government Public Communication. At the beginning of Covid-19 outbreak, government officials did not appear to have a "sense of crisis" and appeared "Anti Science" statements. Minister of Health, Terawan Agus Putranto underestimated Covid-19. He stated that prevention of the coronavirus is not panic and anxiety but enjoying and eat sufficiently. The Minister of Health also rejected the Harvard TH Chan School of Public Health research concluded that the Covid-19 pandemic has spread in Indonesia, although undetected. Asynchronous statements among public officials have caused public doubts about whether or not to lockdown and return home and health protocols [32]. The government has been late establishing a Covid-19 Response Task Force Team (Gugus Tugas Penanggulangan Pandemi Covid-19 or GTPP), on March 13, 2020. In reality, the performance of the GTPP is not optimal. For example GTPP is not optimal build coordination with other institutions because of it just formed by Minister of Home Affairs Letters. The the law hierarchy, It is not a legal product of legislation in Indonesia

At the beginning of the pandemic, there was no reference channel for the dissemination of information on Covid-19 [33]. When the Presidentof Indonesia announced the Covid19 detection first case on March 2, 2020, the public panicked and took actions such as buying up necessities in supermarkets, buying face masks and disinfectant liquid for storage [34]. The Government late released Covid-19 Official Site, on March 18, 2020.

The government is considered ineffective in handling hoax news circulating in the media. Six months since the pandemic, 1729 hoax content spread on Facebook 1237, Instagram 17, Twitter 458, and youtube 1,729 Hoaks [35]. The type of hoax Covid-19, namely, patients died $(58.10 \%)$, the origin of Covid$19(56.30 \%)$, how to protect people from pandemic (for example smoking, drinking alcohol, and others), (54.20\%), how to treat Covid-19, $(45.0 \%)$, places exposed to Covid-19 (45.0\%), ways to prevent the spread of Covid-19 (32,60\%), 
how to protect others from Covid-19 (19.70\%) and others $12.30 \%$. The problem of data in synchronization is also a problem, especially regarding the number of poor people who have caused many problems in the distribution of community assistance [36].

TABLE IV. Comparison of Taiwan and Indonesia Handling Covid-19

\begin{tabular}{|c|c|c|}
\hline Aspects & Taiwan & Indonesia \\
\hline Case detected & January, 20-2020, & March, 2020 \\
\hline Testing Covid- & Population:24 Million & Population:274.519.163 \\
\hline & Total testing: 101.787 & Total testing: 4.488 .738 \\
\hline (til October & Test/1 million population: & Test/1 million populatin: \\
\hline 2020) & 4271. & 16.354 \\
\hline And Tracing & $\begin{array}{l}\text { Tracing, Using digital } \\
\text { technology- FENCE }\end{array}$ & Tracing by medical officer \\
\hline The Institution & $\begin{array}{l}\text { Central Epidemic Command } \\
\text { Center (CECC) for Severe } \\
\text { Special Infectious } \\
\text { Pneumonia. Formed } \\
\text { Januari, } 202020\end{array}$ & $\begin{array}{l}\text { Covid-19 Response Task } \\
\text { Force Team (TGPP) } \\
\text { formed March, } 132020 .\end{array}$ \\
\hline $\begin{array}{l}\text { Public } \\
\text { Communication }\end{array}$ & $\begin{array}{l}\text { Press Conference Covid-19 } \\
\text { by Minister of Healty, } \\
\text { everyday in national media } \\
\text { mass. Using Covid-19 } \\
\text { various channel } \\
\text { (Facebook, Line dan } \\
\text { youtube) }\end{array}$ & $\begin{array}{l}\text { Denial statement of } \\
\text { Covid-19 by public } \\
\text { officials.The government } \\
\text { late released Covid-19 } \\
\text { information channel }\end{array}$ \\
\hline $\begin{array}{l}\text { Preventive } \\
\text { Policies }\end{array}$ & $\begin{array}{l}\text { Social distancing and } \\
\text { quarantine, February, } 2 \\
2020\end{array}$ & $\begin{array}{l}\text { Implementation of The } \\
\text { Large-Scale Social } \\
\text { Restrictions Policy is not } \\
\text { optimal caused too much } \\
\text { requirement and long } \\
\text { procedure }\end{array}$ \\
\hline Sanction & Yes, & $\begin{array}{l}\text { There are no strict } \\
\text { sanctions, sanctions are } \\
\text { only in some areas. }\end{array}$ \\
\hline $\begin{array}{l}\text { Utilization of } \\
\text { technology }\end{array}$ & $\begin{array}{l}\text { Digital Technology, } \\
\text { "FENCE" and M Police }\end{array}$ & $\begin{array}{l}\text { Tracing by medical officer } \\
\text { in some areas }\end{array}$ \\
\hline $\begin{array}{l}\text { Covid-19 } \\
\text { Budgetting }\end{array}$ & Yes & Yes \\
\hline $\begin{array}{l}\text { Economy } \\
\text { Policy }\end{array}$ & Yes & Yes \\
\hline $\begin{array}{l}\text { Social Safety } \\
\text { Net Policy }\end{array}$ & Yes & Yes \\
\hline
\end{tabular}

The Taiwanese government is considered successful in dealing with Covid-19, on the other hand, the Indonesian government has several weaknesses in responding to the Covid-19 pandemic. Some institutions such as the Deep Knowledge Group reported in an article published in Forbes Magazine on April 13, 2020, that Indonesia is a country that has a high category of experiencing failure to handle Covid19. In line with this opinion, the Japan Times stated that Indonesia has failed in handling the Covid-19 pandemic.

Indonesia as the world's fourth-most populous country, where the rate of testing is among the world's lowest, contact tracing is minimal, and authorities have resisted lockdowns even as infections spiked. Indonesia has officially reported 6,346 deaths from COVID-19, the highest overall toll in Southeast Asia. Including people who died with acute COVID-19 symptoms but were not tested, the death toll is three times higher (Japan Times, 20 August,2020) [37].

Some cases showed that the corona virus pandemic has fully shown the weakness of the Indonesian Government as an ineffective administrator [38].

Taiwan's government considered dealing with the spread of the Covid-19 on a large scale which may become a lesson learned for other countries, including Indonesia. The success of the Government in dealing with Covid-19 because of the following factors, first, the ability to make a good plan and conduct a more effective coordination during the critical situation. The Government can hold various actions to prevent the spread of Covid-19, among the optimization of the functions of the CECC for Severe Special Infectious Pneumonia since January 20, 2020, namely coordinating and mobilizing resources to face the Covid-19 pandemic. Taiwan has also re-released an updated version of the Influenza Pandemic Strategic Plan as a basic defense against the pandemic. On the other hand, the Indonesian government seems to ignore Covid-19 pandemic. The statements of officials who denied the existence of Covid-19 in Indonesia. This has resulted in the lack of readiness of the government when the pandemic begins to spread in various regions and the low level of citizen compliance with health protocols. The formation of a coordinating institution, namely the Covid-19 Handling Task Force, on March 13, 2020, was deemed too late. As a result, the government lost its "golden time" to coordinate the handling of Covid-19.

Second, Taiwan has good policies during the pandemic crisis. Taiwan strictly enforces cross-border restrictions, social restrictions, and quarantine for citizens entering Taiwan, accompanied by heavy sanctions for citizens who violate quarantine rules and use of advanced technology. Meanwhile in Indonesia, the implementation of social distancing policies faces obstacles because local governments that will implement social distancing must submit to the central government (Ministry of Health) and meet a number of procedures and criteria. The Ministry of Health has the authority to decide whether an area can implement social distancing on a large scale. In addition, the government's inconsistency in implementing social distancing policies in the regions is by allowing the input of foreign workers in several regions.

Third, Taiwan government was able to formulate public communication and provided the accurate information and data for the citizen. At the beginning, the Taiwan Ministry of Health disseminated public information about Covid-19 in various official channels. The government punished those who spread false information about the pandemic. On the other hand, Indonesia was not a single source of Covid-19 information. It caused fake news or hoaxes to spread widely on various social media. Also, inaccurate data caused the government assistance interventions during the Covid period was miss targets.

In addition, the Government keep the sustainability of health facilities such as preparing medical personnel, care system facilities, availability of personal protective equipment (PPE), adequate Covid-19 testing and supporting technology, including budget support for the health sector and the economic sector. Meanwhile, Indonesia faced limited medical personnel, limited availability of personal protective equipment (PPE), expensive test costs, and the availability of testing facilities such as laboratories which have not been evenly distributed in Indonesia.

\section{IV.CONCLUSION}

Taiwan has successfully handled the spread of Covid-19 in terms of low infection cases and mortality. The 
key to successfully dealing with the Covid-19 pandemic was the government's immediate responses, even before the first case was detected. The Taiwanese government was consistent and determined in containing the spread of the virus through some scenarios such as planning and coordination, policies to prevent the spread of a pandemic, closing entrances in border areas, detect people infected by massive test, tracking out infection cases using digital technology, carry out law enforcement to overcome disinformation, and government public communications in order to eliminate hoaxes. The Government reinforced its citizen's compliance and prevented Covid-19 disinformation by implementing strict sanctions for the disobedient.

In contrast, the Covid-19 handling in Indonesia was relatively slow. In early of pandemic, the public officials tended to deny the virus existence in the country. The Covid-19 handling also faced complicated problems, including disharmony and poor coordination between the central and regional government and related institutions, inconsistency of border entrances policies, limited medical personnel and availability of the personal protective equipment (PPE), the expensive SWAB test compared to other ASEAN countries, as well as poor government public communication.

\section{ACKNOWLEDGMENT}

This article is dedicated to our beloved fellow researcher, Mr. Gunawan. He has left us but our memory stays forever in our heart. He is a wonderful colleague, and we feel very grateful for having him. He has shown us the beautiful value of friendship.

\section{REFERENCES}

[1] I. Alon, F. Matthew, S. Li, "Regime Type and Covid-19 Respon Sagepub.com/journals-permissions-india," FIIB Business Review, 2020, doi: 10.1177/2319714520928884

[2] A. Kavaliunas, P. Ocaya, J.Mumper, I, Lindfeldt, I., \& M. Kyhlstedt, "Swedish Policy Analysis For Covid-19: Health Policy and Technology, Vol 9 (4) p.598-612, 2020

[3] S.R. Nugroho, " Reasons for Taiwan to be the Best Country Responding to the Corona Virus Outbreak " Kompas, 2020, available from: https://www.kompas.com/tren/read/2020/04/08/071500965/inialasan-taiwan-jadi-negara-terbaik-yang-merespons-wabah-viruscorona?page $=$ all, 2020.

[4] Worldometer, WHO Coronavirus Disease (COVID-19) Dashboard, https://covid19.who.int/, 31 October 2020

[5] F. Amat, Arenas, A.F. Gimeno, J. Munoz, "Pandemics meet democracy: Experimental evidence from the COVID-19 crisis in Spain". SocarXivPaper, 2020, doi: 10.31235/osf.io/dkusw

[6] K.M. Eisenhardt, K. M. "Building Theories From Case Study Research. Academy of Management Review, 14(4), 532-550, 1989.

[7] T. R. Dye, "Understanding Public Policy", 13 ${ }^{\text {th }}$ Edition, Pearson Education Inc, New York, 2013

[8] World Health Organzation -WHO, World Health Organzation Report, 2010

[9] J. Summers, C. Hao-Yuan, L. Hsien-Ho, L.T.Barnardf, A. Kvalsvigf A, N. Wilson, M.G Baker, "Potential Lessons From The Taiwan And New Zealand Health Responses To The COVID-19 Pandemic" The Lancet Regional Health - Western Pacific Vol. 4, 2020, doi:10.1016/j.lanwpc.

[10] V.C.R. Hsieh, "Putting Resiliency Of A Health System To The Test: COVID-19 In Taiwan", J Formos Med Assoc Vol 119 (4) 884-895, 2020.

[11] Taiwan Centers for Disease Control (TCDC), “ Taiwan Timely Identifies First Imported Case Of 2019 Novel Coronavirus Infection Returning From Wuhan, China Through Onboard Quarantine Central Epidemic Command Center (CECC) Raises Travel Notice Level For
Wuhan, China To Level 3: Warning', TCDC Taiwan, available from https://www.cdc.gov.tw/En/Bulletin/ Detail/pVg jRVvtHhp94C6GShRkQ?typeid=158, 2020

[12] Taiwan Today, "Implements Extra Inspection Measures for Wuhan flights", available from: https://Taiwantoday.tw/news.php?unit=2,6,10,15,18,\&post=168773. 15 April, 2020

[13] Taiwan Centers for Disease Control-TCDC, Covid-19 (2019-nCoV), available from: https://sites.google.com/cdc.gov.tw/2019-ncov/ Taiwan, 5 September2020.

[14] I. Scher, "Taiwan has only 77 coronavirus cases. Its response to the crisis shows that swift action and widespread healthcare can prevent an outbreak", Business Insider, 2020 https://www.businessinsider.com/coronavirus-taiwan-case-study-rapidresponse-containment-2020-3

[15] CAN, “Taiwan Covid-19 Quarantine Skipper Handed Hefty Finefor Clubbing", available from http;//www.channelnewsasia.com/news/taiwan- taiwan-covid-19clubbing-fine-coronavirus-12567360, 15 April 2020.

[16] K. Wei, "Coronavirus: How Taiwan Is Cracking Up Mask Production To Meetshortfall The Straits Times. Available from: http://www.straitstimes.com/asia/east/coronavirus-how-taiwaniscracking-up-mask-production-to-meet-shortfall, 2020.

[17] Lin C , Mullen J , Braund WE , Pikuei T, Auerbach J, "Reopening safely - Lessons from Taiwan's COVID-19 Response", Journal of Global Health, 11 January 2020.

[18] S. Lin, "Virus Outbreak: Lawmaker Asks Premier To Compensate Medical Workerfor Travel Restriction. Available from: https://taipeitimes.com/News/taiwan/archives/2020/03/04/2003732048, 2020.

[19] N. Li, "Offers Assistance For Virus Woes", Taipei Times, Available from:

https://taipeitimes.com/News/biz/archives/2020/02/14/2002730927, 2020.

[20] D. Broga, "How Taiwan Use Tech To Fight Covid-19. Technology UK. Available from: http://www.techik.org/insight/news/item/17187 how-taiwan-use-tech- to- fight-covid-19, 2020

[21] M. Hui, "How Taiwan Is Tracking 55,000 People Under Home Quarantine In Real Time" Available from: https://qz.com/1825997/Taiwan-phone-tracking-system monitors55000-under-coronavirus-quarantine, 2020

[22] L. Agustino, "Analysis Of Covid-19 Outbreak Handling Policy: The Experience Of Indonesia": Administration Borneo Journal, Vol 16 (2) p. 253-270, 2020.

[23] W. Mas'udi w, P.S. Winanti, “ Covid-19 From a Health Crisis to a Governance Crisis. Part of the Governance Book for Handling Covid19 in Indonesia Preliminary studies", Gadjah Mada University Press, Yogyakarta,2020.

[24] S. Chadijah, "Harmonization of Authority in Handling the Covid-19 Pandemic Between Central and Regional Governments": Kertha Semaya Journal, Vol 8 (6), p. 858-866, 2020

[25] CNN Indonesia, " PSBB Jakarta, Jokowi asks the regions not to immediately close down their territories", available from: https://www.cnnindonesia.com/nasional/20200915090959-20546540/psbb-jakarta-jokowi-minta-daerah-tak-buru-buru-tutupwilayah, 2020

[26] CNN Indonesia, "Corona Test Tool, Indonesia Is Ready To Distribute. Indonesia Insinuated Still Import", available from: https://www.cnnindonesia.com/teknologi/20200928141733-199551846/alat-tes-corona-ri-siap-edar-pemerintah-disindir-masih-impor, 2020.

[27] T. Khairil, "The Indonesian Government's Response to the Covid-19 Pandemic: Early Desecuritization, Obstained Securitization" Binus University, available from: https://ir.binus.ac.id/2020/03/23/responspemerintah-indonesia-terhadap-pandemi-covid-19-desekuritisasi-diawal-sekuritisasi-yang-terhambat/, 2020.

[28] T.A. Salsabila, "The Discourse on Handling Covid-19 by the Central and Local Governments: Is the Large-Scale Social Restriction Policy (PSBB) Implemented Effectively. UNPAD University, available from: https://fh.unpad.ac.id/diskursus-penanganan-covid-19-olehpemerintah-pusat-dan-daerah-efektifkah-kebijakan-pembatasan-sosialberskala-besar-psbb-diterapkan/, 2020.

[29] A. Muin, "Not Want to Implement PSBB, Regent Maros: Look at Makassar and Gowa," IDN Times News, available from: https://sulsel.idntimes.com/news/sulsel/ashrawi-muin/belum-mau- 
terapkan-psbb-bupati-maros-lihat-dulu-makassar-dan-gowa/3, 2020.

[30] Rachmawati, "When 500 Foreign Workers From China Will Be Brought In Amidst The Corona Pandemic, Claims To Avoid Layoffs Of Chinese Workers' Koran Kompas, available from: https://regional.kompas.com/read/2020/05/03/06400071/saat-500-tkaasal-china-akan-didatangkan-di-tengah-pandemi-corona-

klaim?page $=$ all, 2020.

[31] M.Arnani,"202 Doctor Died of Covid-19”.Kompas.Com., available from: https://www.kompas.com/tren/read/2020/12/15/203100365/idi- 202-doctor-died-of-covid-19? Page $=$ all, 2020

[32] Worldometer, WHO, available from: https://covid19. who.int/?gclid=Cj0KCQiA5vb-BRCRARIsA, $\quad 3$ November 2020

[33] Universitas Gajah Mada, "Infodemic Problem Responding to The Covid-19 Pandemic," UGM, available from:

https://fisipol.ugm.ac.id/wp-

content/uploads/sites/1056/2020/04/Policy-Brief-Problem-Infodemicdalam-Merespon-Pandemi-COVID-19.pdf , 2020.

[34] Koran Tempo News, "WHO Highlights Health Facilities in Regions, Koran Tempo, Available from:https://koran.tempo.co/read/beritautama/450687/who-soroti-fasilitas-kesehatan-di-daerah, 2020.

[35] Ministry of Communication and Information,"Imprisonment and fine of 1 billion Imprisonment and fine of 1 billion", available from https://kominfo.go.id/content/detail/25923/kominfopenyebar-hoakscovid-19-diancam-sanksi-kurungandan-denda-1-miliar/0/virus_corona, 2020.

[36] C. Juditha, "Community Behavior Related to the Spread of the Covid19 Hoax,": Pekommas Journal, Vol. 5 No. 2, p. 105 - 116, 2020

[37] Japan Times, "An Endless First Wave: How Indonesia Failed To Control The Virus. available from:https://www.japantimes.co.jp/news/2020/08/20/asiapacific/indonesia-failed-to-control-coronavirus/, 2020

[38] J. Kurlantzick, How Jokowi Failed Handling Corona (COVID-19). available from: https://www.matamatapolitik.com/bagaimana-jokowigagal-dalam-ujian-covid-19-analisis/, 2020. 